\title{
Heterotrophic nitrification-aerobic denitrification potential of cyanide and thiocyanate degrading microbial communities under cyanogenic conditions
}

\author{
Lukhanyo Mekuto ${ }^{\dagger}$, Young Mo Kim², Seteno K. O. Ntwampe', Maxwell Mewa-Ngongang ${ }^{1,3}$, \\ John Baptist N. Mudumbi ${ }^{1}$, Nkosikho Dlangamandla ${ }^{1}$, Elie Fereche Itoba-Tombo ${ }^{1}$, E. A. Akinpelu ${ }^{1}$ \\ ${ }^{1}$ Bioresource Engineering Research Group (BioERG), Department of Biotechnology, Cape Peninsula University of Technology, Cape Town 8000, South Africa \\ ${ }^{2}$ School of Environmental Science and Engineering, Gwangju Institute of Science and Technology, Gwangju 61005, Republic of Korea \\ ${ }^{3}$ Department of Microbiology, Agricultural Research Council, Private bag X5026, Stellenbosch 7599, South Africa
}

\begin{abstract}
The impact of free cyanide $\left(\mathrm{CN}^{-}\right)$and thiocyanate $\left(\mathrm{SCN}^{-}\right)$on the $\mathrm{CN}^{-}(\mathrm{CDO})$ and $\mathrm{SCN}^{-}$degraders $(\mathrm{TDO})$ to nitrify and denitrify aerobically was evaluated under alkaline conditions. The CDO's were able to nitrify under cyanogenic conditions, achieving $\mathrm{NH}_{4}{ }^{+}-\mathrm{N}$ removal rates above $1.66 \mathrm{mg} \mathrm{NH}_{4}{ }^{+} \mathrm{N}_{\mathrm{L}} \mathrm{L}^{-1} \cdot \mathrm{h}^{-1}$, except when $\mathrm{CN}^{-}$and SCN $\mathrm{SC}^{-}$loading was $15 \mathrm{mg} \mathrm{CN} / \mathrm{L}$ and $50 \mathrm{mg} \mathrm{SCN} \cdot \mathrm{L}^{-1}$, respectively, which slightly inhibited nitrification. The TDO's were able to achieve a nitrification rate of $1.59 \mathrm{mg} \mathrm{NH}{ }_{4}^{+}-\mathrm{N}^{-1} \cdot \mathrm{L}^{-1} \cdot \mathrm{h}^{-1}$ in the absence of both $\mathrm{CN}^{-}$and $\mathrm{SCN}^{-}$, while the presence of

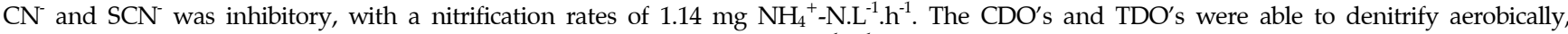
with the CDO's obtaining $\mathrm{NO}_{3}^{-}-\mathrm{N}$ removal rates above $0.67 \mathrm{mg} \mathrm{NO}{ }_{3}^{-}-\mathrm{N}^{-1} \cdot \mathrm{L}^{-1} \cdot \mathrm{h}^{-1}$, irrespective of the tested $\mathrm{CN}^{-}$and $\mathrm{SCN}^{-}$concentration range. Denitrification by the TDO's was inhibited by $\mathrm{CN}^{-}$, achieving a removal rate of $0.46 \mathrm{mg} \mathrm{NO}{ }^{-}-\mathrm{N}^{-1} \mathrm{~L}^{-1} \cdot \mathrm{h}^{-1}$ and $0.22 \mathrm{mg} \mathrm{NO}_{3}^{-}-\mathrm{N}^{-1} \mathrm{~L}^{-1} \cdot \mathrm{h}^{-1}$ when $\mathrm{CN}^{-}$ concentration was 10 and $15 \mathrm{mg} \mathrm{CN} \cdot \mathrm{L}^{-1}$, respectively. However, when the CDO's and TDO's were co-cultured, the nitrification and aerobic denitrification removal rates were $1.78 \mathrm{mg} \mathrm{NH}{ }_{4}^{+}-\mathrm{N} \cdot \mathrm{L}^{-1} \cdot \mathrm{h}^{-1}$ and $0.63 \mathrm{mg} \mathrm{NO}{ }_{3}^{-}-\mathrm{N}^{-1} \cdot \mathrm{L}^{-1} \cdot \mathrm{h}^{-1}$ irrespective of $\mathrm{CN}^{-}$and $\mathrm{SCN}^{-}$concentrations.
\end{abstract}

Keywords: Aerobic denitrification, Cyanide degraders, Free cyanide, Nitrification, Thiocyanate, Thiocyanate degrader

\section{Introduction}

Biodetoxification of industrial effluent containing hazardous compounds is an important process used in wastewater treatment technology. Such processes are characterized by (i) low capital costs, (ii) environmental benignity and (iii) allows for the complete remediation of the wastewater, unlike chemical and physical processes that produce by-products which contribute to environmental deterioration. These chemical and physical processes are utilized in the degradation of cyanide and related compounds found in metallurgical and mineral processes where free cyanide $\left(\mathrm{CN}^{-}\right)$ is utilized as a lixiviant for the recovery of precious metals from gold bearing ores in a process known as the cyanidation process [1]. Due to the environmental severity of such processes, biodegradation of cyanide and related compounds is preferable as it is more environmentally benign. However, this process results in the production of ammonium (Eq. (1) and (2)), which is regarded as a pollutant. Furthermore, wastewater containing elevated concentrations of ammonium can contaminate potable and surface waters resulting in eutrophication.

$$
\begin{gathered}
\mathrm{CN}^{-}+\mathrm{O}_{2}+\mathrm{H}_{2} \mathrm{O} \rightarrow \mathrm{HCO}_{3}^{-}+\mathrm{NH}_{4}^{+} \\
\mathrm{SCN}^{-}+2 \mathrm{O}_{2}+2 \mathrm{H}_{2} \mathrm{O} \rightarrow \mathrm{NH}_{4}^{+}+\mathrm{SO}_{4}^{2-}+\mathrm{CO}_{2}
\end{gathered}
$$

Biological nitrogen removal (BNR) is commonly utilized for the effective removal of nitrogenous compounds in wastewater. Traditional BNR systems consist of two steps: Nitrification by autotrophs under aerobic conditions, followed by denitrification by heterotrophs under anoxic conditions [2]. However, this system

Received April 13, 2018 Accepted July 26, 2018

${ }^{\dagger}$ Corresponding author

Email: Lukhayo.Mekuto@gmail.com

Tel: +27-21-460-9097 Fax: +27-21-460-3282

ORCID: 0000-0003-3069-4624 
is associated with the following shortcomings: (i) the nitrification step is slow due to the low growth rate of autotrophs; (ii) autotrophs are vulnerable to high concentrations of ammonium and organic matter; and (iii) nitrification and denitrification reactors are separated due to the aerobic and anaerobic nature of the organisms employed in nitrification and denitrification, respectively [3, 4]. However, recently, heterotrophic organisms capable of nitrification and denitrification under aerobic conditions have been reported. Novel bacterial species such as Bacillus methylotrophicus L7 [5], Pseudomonas stutzeri YZN-001 [6], Rhodococcus sp. CPZ24 [7], Alcaligenes faecalis C16 [8] and other species have been reported to undergo heterotrophic nitrification and aerobic denitrification. These systems are associated with high nitrogen removal efficiencies due to the high growth rate of the microorganisms used in such systems. Utilizing these microorganisms, in comparison to traditional autotrophic nitrifying and anoxic denitrifying organisms, has the following advantages: (i) Heterotrophs grow rapidly, therefore microbial recycling is not required, (ii) Nitrification and denitrification can be achieved simultaneously, (iii) Minimal acclimation problems are observed, (iv) There is no need for $\mathrm{pH}$-control, as the acidity that is generated during heterotrophic nitrification would be offset by the alkalinity produced during aerobic denitrification, (v) Heterotrophic nitrifiers are tolerant to low temperatures as compared to autotrophic organisms [2, 4, 8].

However, limited research has been conducted to evaluate the susceptibility of heterotrophic nitrifiers and aerobic denitrifiers to $\mathrm{CN}^{-}$and thiocyanate ( $\mathrm{SCN}^{-}$) compounds in relation to the overall treatment of cyanide species found in cyanidation wastewater. A similar system where the presence of $\mathrm{CN}^{-}, \mathrm{SCN}^{-}$and phenol on autotrophic nitrifying and denitrifying organisms has been reported; however such a system was related to the remediation of cokes and gasification wastewaters [9], which have disparate contaminants compared to cyanidation wastewater. Therefore, there is a need for the evaluation of $\mathrm{CN}^{-}$and $\mathrm{SCN}^{-}$degrading organisms to conduct heterotrophic nitrification and aerobic denitrification under cyanogenic conditions since the biodegradation of $\mathrm{CN}^{-}$and $\mathrm{SCN}^{-}$is rarely complete, especially during the cold season. Hence, this study was aimed at evaluating the heterotrophic nitrification and aerobic denitrification propensity of $\mathrm{CN}^{-}$and $\mathrm{SCN}^{-}$degrading organisms, with the overall aim of applying the same organisms in the biodegradation of $\mathrm{CN}^{-}$and $\mathrm{SCN}^{-}$and its related complexes.

\section{Materials and Methods}

\subsection{Inoculum Preparation: Thiocyanate Degrading Organisms (TDO)}

The thiocyanate degrading microbial consortia used in this study were sampled from an active lab-scale $\mathrm{SCN}^{-}$degradation system operated at the Bioresource Engineering Research Group (BioERG) laboratories, Cape Town, South Africa. The TDO's were analyzed using the $16 \mathrm{~S}$ rDNA amplicon gene sequencing approach to reveal the microbial species that were present within the microbial community and this data is available in Mekuto et al. [10].
For inoculum development, the reactor used had a height of $250 \mathrm{~mm}$ and a diameter of $104 \mathrm{~mm}$ with an operating volume of $1 \mathrm{~L}$. Aeration was set to $0.4 \mathrm{~L} \mathrm{~min}^{-1}$ and the system was operated at room temperature $\left(20\right.$ to $\left.22^{\circ} \mathrm{C}\right)$. Mixing was achieved using an overhead stirrer fitted with 2-x-four bladed Rushton-type impellers, set at $250 \mathrm{rpm}$. The sample was centrifuged at 14,000 rpm for $5 \mathrm{~min}$ to concentrate the microbial cells. The cells were washed twice with a phosphate buffer solution $(\mathrm{pH}=7.0)$ and thereafter, the cells were re-suspended in sterile distilled water subsequent to inoculation $(1 \% \mathrm{v} / \mathrm{v})$ in a nitrogen-free minimal media $(\mathrm{MM})(\mathrm{pH}=9.9)$ as described previously by Mekuto et al. [11], with glucose being used as a carbon source at a concentration of $1 \mathrm{gL}^{-1}$. The cells were grown for a period of $48 \mathrm{~h}$ at a temperature of $30^{\circ} \mathrm{C}$ in $250 \mathrm{~mL}$ Erlenmeyer flasks containing $200 \mathrm{~mL}$ of MM. This culture was then used to study the potential of the organisms to conduct heterotrophic nitrification and aerobic denitrification under cyanogenic conditions.

\subsection{Inoculum Preparation: Cyanide Degrading Organisms (CDO)}

Similarly, the $\mathrm{CN}^{-}$degrading consortium was sampled from a stock reactor treating $\mathrm{CN}^{-}$containing wastewater operated at the BioERG laboratories, Cape Town, South Africa. The configuration of the reactor was as described in section 2.1. This mixed microbial community were identified using $16 \mathrm{~S}$ rDNA amplicon gene sequencing and the data is available in [10]. These bacterial species were previously isolated from $\mathrm{CN}^{-}$containing wastewater and were previously found to be cyanide degraders by [12], but were unable to degrade thiocyanate (data not shown). The inoculum was derived from the reactor using the procedures highlighted in section 2.1.

\subsection{Experimental Design}

\subsection{1. $\mathrm{CN}^{-}$and $\mathrm{SCN}^{-}$biodegradation by $\mathrm{CDO}$ 's and TDO's}

To prove $\mathrm{CN}^{-}$and $\mathrm{SCN}^{-}$biodegradation by CDO's and TDO's, respectively, $\mathrm{MM}$ was adjusted to a $\mathrm{pH}$ of 9.9 and the $\mathrm{CN}^{-}$and $\mathrm{SCN}^{-}$concentrations were set at $250 \mathrm{mg} \mathrm{CN} \cdot \mathrm{L}^{-1}$ and $200 \mathrm{mg}$ $\mathrm{SCN}^{-} . \mathrm{L}^{-1}$. Furthermore, the CDO's and TDO's were co-cultured to assess dual SCN and $\mathrm{CN}$ biodegradation capacity in the same media using the concentrations stated. The $\mathrm{CN}^{-}$biological removal efficiency (BRE \%) was calculated as defined in [11]. All experimental work containing $\mathrm{CN}^{-}$were conducted in airtight multiport shake flasks fitted with a syringe port to allow for sampling without opening the flask contents. This was done to prevent the volatilisation of $\mathrm{CN}^{-}$as hydrogen cyanide gas. Uninoculated flasks served as controls. The experimental error was calculated as the standard error of mean using the standard deviation obtained from a duplicate set of data $(\mathrm{n}=2)$.

\subsubsection{Heterotrophic nitrification and aerobic denitrification by CDO and TDO: Effect of $\mathrm{CN}^{-}$and $\mathrm{SCN}^{-}$}

To assess the capacity of TDO's and CDO's to conduct heterotrophic nitrification and aerobic denitrification, the cultures were inoculated in $200 \mathrm{~mL}$ flasks with $\mathrm{MM}$, containing an initial concentration of ammonium (as $\mathrm{NH}_{4} \mathrm{Cl}$ ) and nitrate (as $\mathrm{NaNO}_{3}$ ) of 250 mg $\mathrm{NH}_{4}{ }^{+}-\mathrm{N} . \mathrm{L}^{-1}$ and $100 \mathrm{mg} \mathrm{NO}{ }^{-}-\mathrm{N}^{-L^{-1}}$, respectively. The effect 
of $\mathrm{SCN}^{-}$and $\mathrm{CN}^{-}$on nitrification and denitrification was assessed by supplementing the required concentrations of $\mathrm{SCN}^{-}$(25 and $50 \mathrm{mg} \mathrm{SCN} \cdot \mathrm{L}^{-1}$ ) (as KSCN) and $\mathrm{CN}^{-}\left(5,10\right.$ and $\left.15 \mathrm{mg} \mathrm{CN} . \mathrm{L}^{-1}\right)$ (as NaCN) (Merck, Germany). The dual effect of both $\mathrm{SCN}^{-}$and $\mathrm{CN}^{-}$was also assessed at $25 \mathrm{mg} \mathrm{SCN} \cdot \mathrm{L}^{-1}$, while $\mathrm{CN}^{-}$was varied as stated previously. The effect of $\mathrm{CN}^{-}$and $\mathrm{SCN}^{-}$on $\mathrm{CN}^{-}$and $\mathrm{SCN}^{-}$degraders was evaluated separately and in co-cultures. Oxygen sparging was not used to oxygenate the nutrient media, thus the organisms relied solely on the dissolved oxygen (DO) in the wastewater, which was equivalent to $\sim 5$ mg. $\mathrm{L}^{-1}$ (BANTE820 portable dissolved oxygen meter, BANTE instruments, China). The DO was measured prior to the commencement of the experimental work and was not monitored thereafter. The $\mathrm{pH}$ of the media was set at 9.9 and at a temperature of $30^{\circ} \mathrm{C}$ for both nitrification and denitrification studies. These conditions were based on (i) the fact that cyanide containing wastewaters are mostly alkaline [13, 14] and (ii) previous optimization studies on cyanide degrading organisms observed these conditions as being most suitable for successful $\mathrm{CN}^{-}$biodegradability [15]; hence these conditions were chosen on a pragmatic basis. The nitrification and denitrification rates were reported as averaged rates. Uninoculated flasks served as controls while the experimental error was calculated as the standard error of mean using the standard deviation obtained from a duplicate set of data $(n=2)$.

\subsection{Analytical Methods}

The collected samples were centrifuged at 14,000 rpm for $5 \mathrm{~min}$ and then analysed for ammonium, nitrate, nitrite, $\mathrm{CN}^{-}$using Merck ammonium (00683), nitrate (14773), nitrite (14776), cyanide (09701) and sulphate (00617) test kits. The basis behind the mechanism of determination of these compounds using Merck test kits has been elucidated by Mekuto et al. [11]. Thiocyanate was determined using the ferric method [16]. The $\mathrm{pH}$ was measured using a Crison Basic20 pH meter, which was calibrated daily.

\section{Results and Discussion}

\subsection{Thiocyanate and Cyanide Biodegradation by $\operatorname{CDO}$ and TDO}

The degradation of $\mathrm{SCN}^{-}$and $\mathrm{CN}^{-}$by $\mathrm{TDO}$ and $\mathrm{CDO}$ was assessed in batch systems under alkaline conditions. The TDO were sampled from an active $\mathrm{SCN}^{-}$biodegradation system and were observed to have a $\mathrm{SCN}^{-}$degradation efficiency of $100 \%$ after $96 \mathrm{~h}$ (Fig. 1(a)), resulting in ammonium nitrogen and sulphate formation. The sulphate concentration increased to $90 \mathrm{mg} \mathrm{SO}{ }_{4}^{2-\mathrm{L}^{-1}}$ at $72 \mathrm{~h}$ and thereafter, plateaued. Additionally, ammonium nitrogen increased logarithmically after $27 \mathrm{~h}$ to $104 \mathrm{mg} \mathrm{NH}_{4}^{+}-\mathrm{N} \cdot \mathrm{L}^{-1}$. There was an observed $\mathrm{pH}$ decrease during $\mathrm{SCN}^{-}$degradation, which declined from an initial $\mathrm{pH}$ of 9.9 to 7.53. This was due to the acid produced from the oxidation of reduced sulphur species, thus resulting in a $\mathrm{pH}$ decrease. This is one of the few studies reporting on the degradation of $\mathrm{SCN}^{-}$under alkaline conditions since most studies are focused on the degradation of $\mathrm{SCN}^{-}$ under neutral $\mathrm{pH}$ conditions $[17,18]$. Wastewaters generated from metallurgical processes are mostly alkaline [19]; hence,
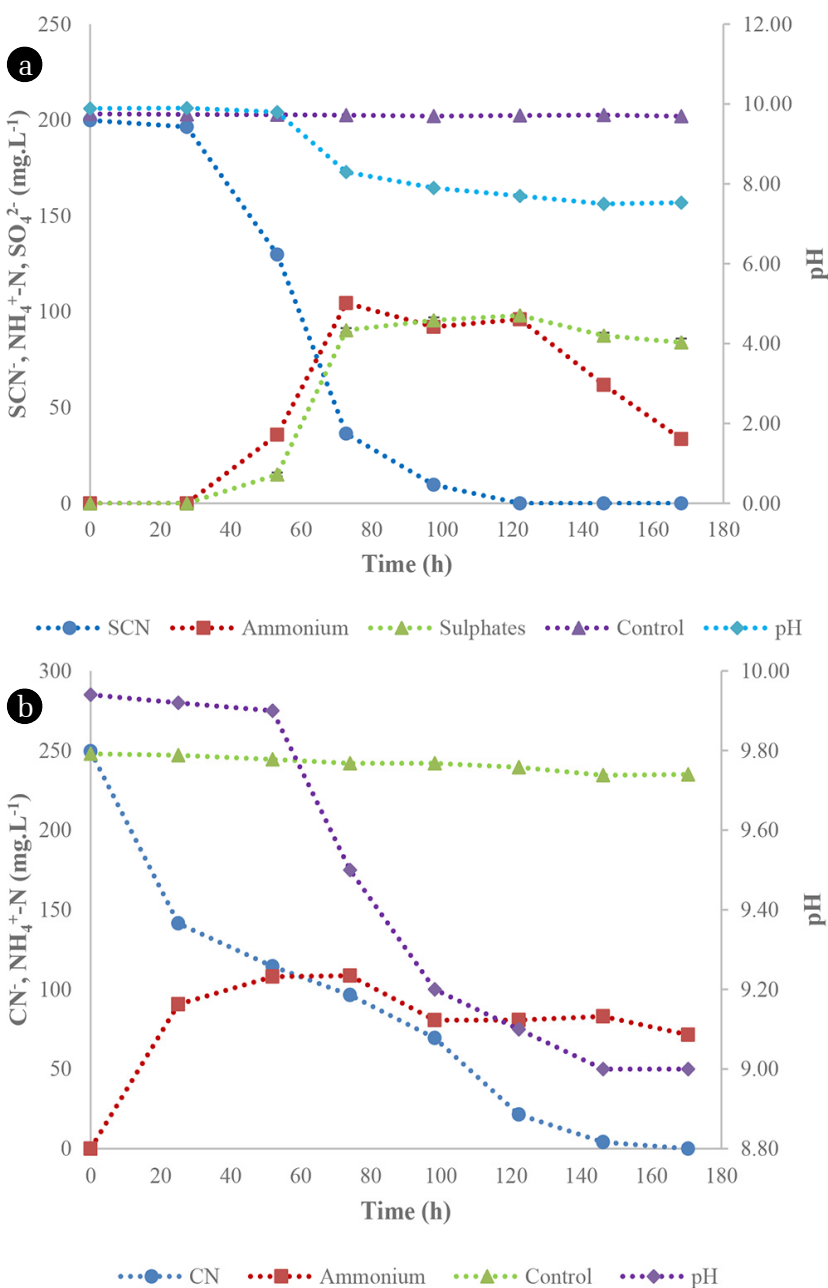

Fig. 1. Biodegradation profiles of, (a) thiocyanate by TDO and (b) free cyanide by $\mathrm{CDO}$. Error bars represent deviations.

studies undertaken in such conditions are vital. Sorokin et al. [20] demonstrated the capacity of the Halomonas and Thioalkalivibrio species to biodegrade $\mathrm{SCN}^{-}$under alkaline conditions and observed that these microbial species were able to degrade $\mathrm{SCN}^{-}$, producing cyanate, which was subsequently utilised by the organisms. Furthermore, Thioalkalivibrio thiocyanodenitrificans degraded $\mathrm{SCN}^{-}$aerobically and anaerobically under alkaline conditions, demonstrating the effectiveness of the applied microbial organisms [21].

The CDO were maintained in $\mathrm{CN}^{-}$containing media prior to preparation of the inoculum, which resulted in increased capacity of the organisms to biodegrade as they were able to achieve a BRE of $99.9 \%$ after $170 \mathrm{~h}$ (Fig. 1(b)). $\mathrm{CN}^{-}$decreased drastically during the initial $24 \mathrm{~h}$ of incubation and this observation may be due to the secretion of extracellular cyanide-degrading enzymes, a phenomenon which was observed by [12]. From the same study [12], similar microbial species which were not adapted to $\mathrm{CN}^{-}$, resulted in a BRE of only $57 \%$ from an initial concentration of $300 \mathrm{mg} \mathrm{CN}: \mathrm{L}^{-1}$. This observation demonstrated the effectiveness of microbial adaptation for improved capacity of the consortia 
to biodegrade. However, the CDO were observed to be unable to degrade $\mathrm{SCN}^{-}$(data not shown). Overall, there was an insignificant decrease in $\mathrm{pH}$ during the biodegradation process.

\subsection{Effect of Thiocyanate and Free Cyanide on Heterotrophic Nitrification by TDO and CDO}

Heterotrophic nitrification under non- $\mathrm{SCN}^{-}$containing conditions by the members of the TDO community resulted in a nitrification rate of $1.59 \mathrm{mg} \mathrm{NH}{ }_{4}^{+}-\mathrm{N} . \mathrm{L}^{-1} \cdot \mathrm{h}^{-1}$ while there was an observed inhibition on heterotrophic nitrification, where the nitrification rate decreased to 0.95 and $0.44 \mathrm{mg} \mathrm{NH}{ }_{4}^{+}-\mathrm{N}^{-1} \mathrm{~L}^{-1} \cdot \mathrm{h}^{-1}$ in media containing 25 and $50 \mathrm{mg} \mathrm{SCN} \cdot \mathrm{L}^{-1}$, respectively (Fig. 2(a)). After nitrification, $\mathrm{SCN}^{-}$was not detected in the media (data not shown), suggesting its complete biodegradation. Nitrification rates under $\mathrm{CN}^{-}$concentration of 5,10 and $15 \mathrm{mg} \mathrm{CN} \cdot \mathrm{L}^{-1}$ were observed to be 1.14 , 0.57 and $0.32 \mathrm{mg} \mathrm{NH}{ }_{4}^{+}-\mathrm{N} . \mathrm{L}^{-1} \cdot \mathrm{h}^{-1}$, respectively (Fig. 2(b)). This demonstrated the acute toxicity and inhibition of nitrification by $\mathrm{CN}^{-}$. This phenomena was observed elsewhere [22], where $0.11 \mathrm{mg} \mathrm{CN} . \mathrm{L}^{-1}$ was suggested to be an accepted concentration for nitrification to transpire. The presence of both $\mathrm{CN}^{-}$(varying concentration) and $\mathrm{SCN}^{-}\left(25 \mathrm{mg} \mathrm{SCN}^{-} \cdot \mathrm{L}^{-1}\right)$ proved to be detrimental on nitrification by TDO's as the nitrification rates decreased drastically. The observed nitrification rates were 1.0, 0.51 and $0.301 \mathrm{mg} \mathrm{NH}{ }_{4}^{+}-\mathrm{N} . \mathrm{L}^{-1} \cdot \mathrm{h}^{-1}$ from the initial concentrations of 5,10 and $15 \mathrm{mg} \mathrm{CN} \cdot \mathrm{L}^{-1}$ while the $\mathrm{SCN}^{-}$concentration was kept at $25 \mathrm{mg} \mathrm{SCN}$. $^{-1}$, respectively (Fig. 2(c)). The utilisation of ammonium nitrogen by the TDO's resulted in the production of both nitrates and nitrites within the media. The maximum concentration of nitrates produced from the media supplemented with 0, 25, $50 \mathrm{mg} \mathrm{SCN} \cdot \mathrm{L}^{-1}$ and 5, 10, $15 \mathrm{mg} \mathrm{CN}^{-} . \mathrm{L}^{-1}$ was 136, 44, 1.65 (Fig. 3(a)) and 68, 32.4 and $24.7 \mathrm{mg} \mathrm{NO}{ }^{-}-\mathrm{N}^{-L^{-1}}$, respectively (Fig. 3(b)). Similarly, the maximum nitrate nitrogen concentration from the dual impact of $\mathrm{SCN}^{-}$and $\mathrm{CN}^{-}$was 46.5, 37 and $15 \mathrm{mg}$ $\mathrm{NO}_{3}{ }^{-}-\mathrm{N} . \mathrm{L}^{-1}$, respectively (Fig. 3(c)). The nitrite nitrogen concentration in all the tested media was less than $20 \mathrm{mg} \mathrm{NO}{ }_{2}{ }^{-} \mathrm{N} . \mathrm{L}^{-1}$. In this study, it was observed that the nitrate nitrogen formation rate from ammonium oxidation was not in a 1:1 ratio as defined by Eq. (3) This was due to the utilization of the ammonium as a nitrogen source by the consortium; hence, a portion of the ammonium nitrogen was used intracellularly by the employed microbial organisms, resulting in low nitrate nitrogen detection in the media. This was also observed when Alcaligenes faecalis (A. faecalis) No.4 heterotrophically oxidised ammonium nitrogen, resulting in the lower detection of nitrates within the media [3]. The authors observed that $50 \%$ of the ammonium nitrogen was utilised intracellularly by $A$. faecalis No.4 and almost 39 to $48 \%$ was denitrified simultaneously and/or immediately after formation. It is imperative to note that the percentage of ammonium nitrogen that is utilised intracellularly varies between species and strains. Additionally, heterotrophic nitrifying organisms have been observed to have the ability to simultaneously nitrify and denitrify aerobically in the same media [7, 23, 24]. Therefore, the low detection of nitrates in the media was attributed to its utilisation by the microbial species.

$$
\mathrm{NH}_{4}^{+}+2 \mathrm{O}_{2} \rightarrow \mathrm{NO}_{3}^{-}+\mathrm{H}_{2} \mathrm{O}+2 \mathrm{H}^{+}
$$
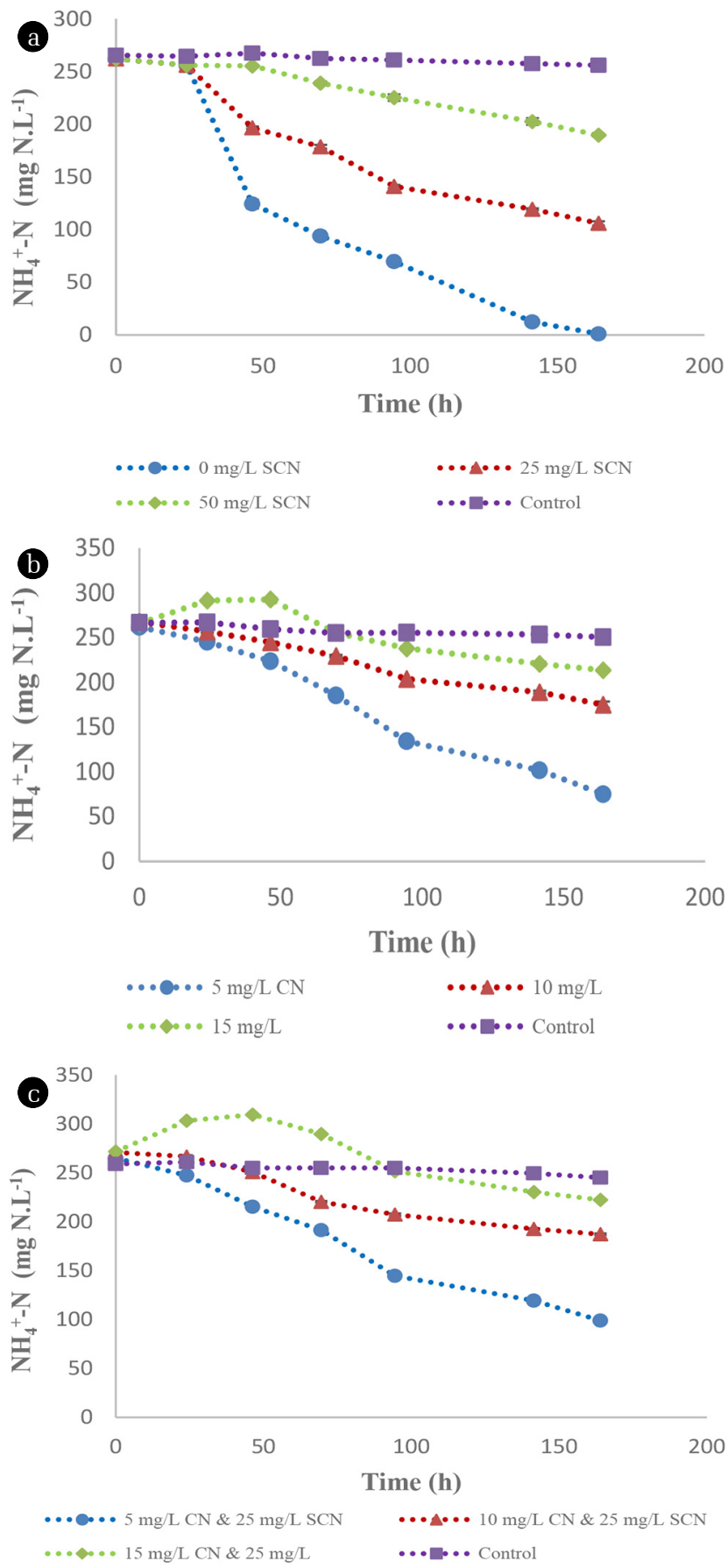

Fig. 2. Heterotrophic nitrification profiles by TDO under, (a) varying thiocyanate concentration, (b) varying free cyanide concentrations and (c) a combination of thiocyanate and free cyanide. Error bars represent deviations.

Heterotrophic nitrification by the CDO's proved to be robust as these species were unaffected by the presence of both $\mathrm{SCN}^{-}$ and $\mathrm{CN}^{-}$. These organisms demonstrated high nitrification rates of 1.66, 1.67 and $1.47 \mathrm{mg} \mathrm{NH}{ }_{4}{ }^{+}-\mathrm{N} . \mathrm{L}^{-1} \cdot \mathrm{h}^{-1}$ in media spiked with 0, 25 and 50 mg SCN.$L^{-1}$, respectively (Fig. 4(a)). Similarly, $\mathrm{CN}^{-}$ 

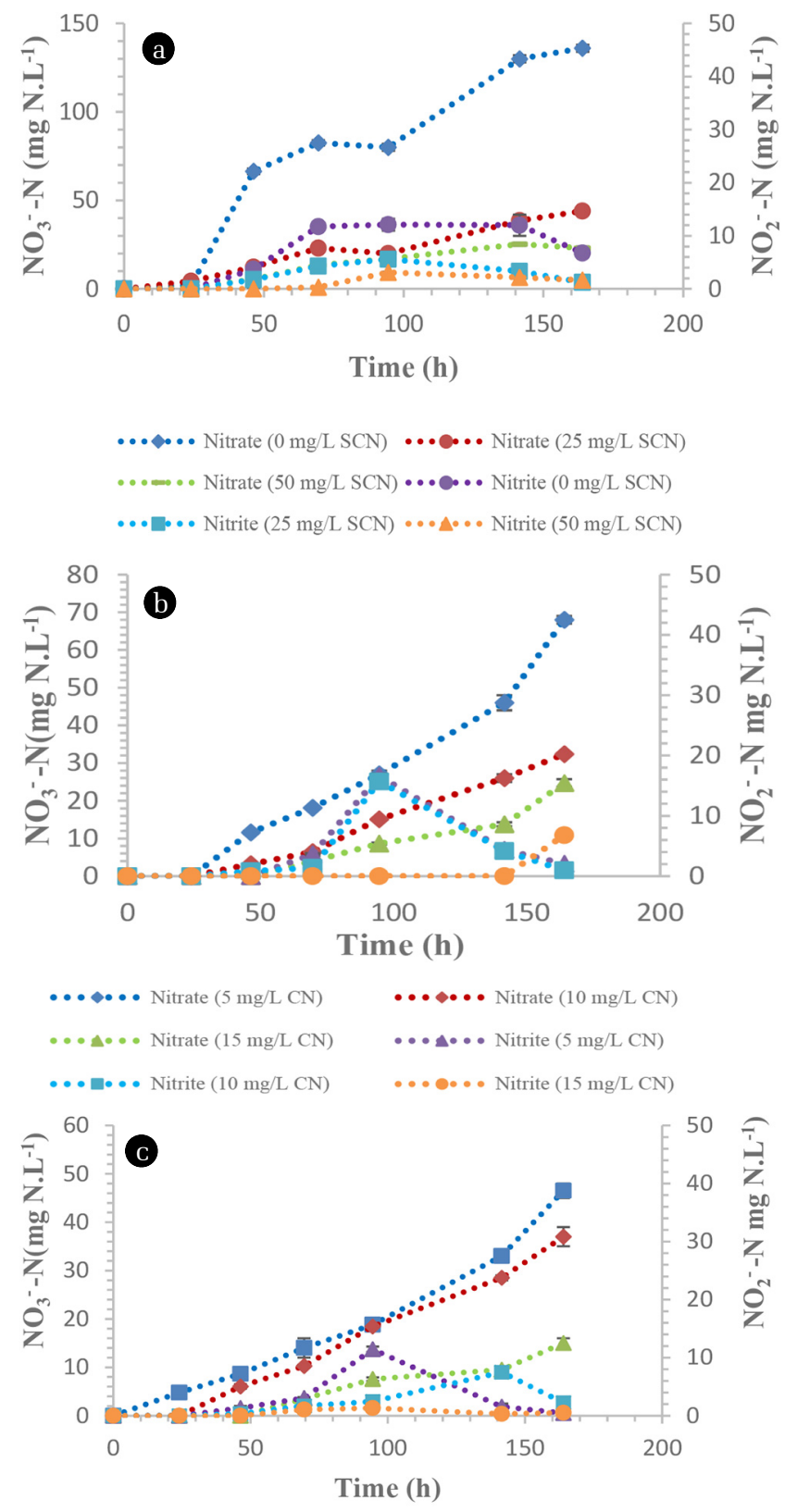

... ש... Nitrate $(25 \mathrm{mg} / \mathrm{L} \mathrm{SCN} \& 5 \mathrm{mg} / \mathrm{L} \mathrm{CN}) \quad$... ... Nitrate $(25 \mathrm{mg} / \mathrm{L} \mathrm{SCN} \& 10 \mathrm{mg} / \mathrm{L} \mathrm{CN})$

•..... Nitrate $(25 \mathrm{mg} / \mathrm{L} \mathrm{SCN} \& 15 \mathrm{mg} / \mathrm{L} \mathrm{CN}) \quad$... . . Nitrite $(25 \mathrm{mg} / \mathrm{L} \mathrm{SCN} \& 5 \mathrm{mg} / \mathrm{L} \mathrm{CN})$

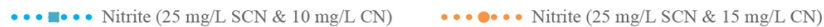

Fig. 3. $\mathrm{NO}_{3}^{-}$and $\mathrm{NO}_{2}^{-}$formation profiles from heterotrophic nitrification by TDO under, (a) varying $\mathrm{SCN}^{-}$concentration, (b) varying $\mathrm{CN}^{-}$ concentration and (c) a combination of $\mathrm{SCN}^{-}$and $\mathrm{CN}^{-}$. Error bars represent deviations.

concentration did not have any inhibitory effect on CDO's as they were able to achieve nitrification rates of $1.63,1.66$ and $1.47 \mathrm{mg} \mathrm{NH}{ }^{+}-\mathrm{N} \cdot \mathrm{L}^{-1} \cdot \mathrm{h}^{-1}$ from media spiked with 5,10 and 15 mg CN. $\mathrm{L}^{-1}$, respectively (Fig. 4(b)). Furthermore, the organisms demonstrated their effectiveness as these species were not in
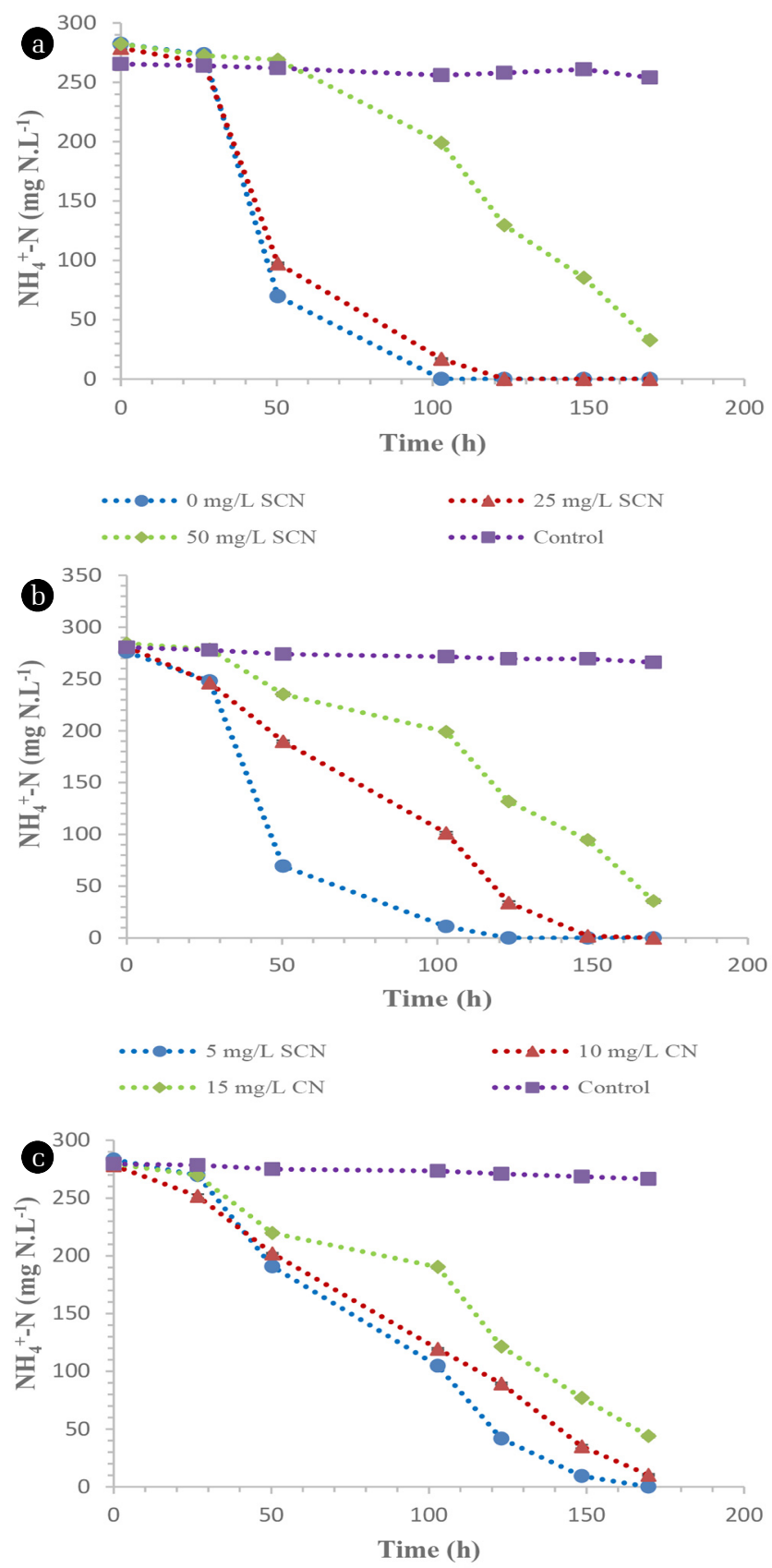

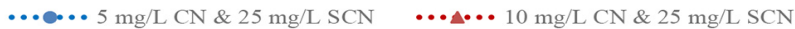

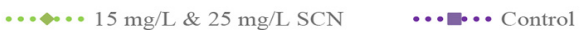

Fig. 4. Heterotrophic nitrification profiles by $\mathrm{CDO}$ under, (a) varying $\mathrm{SCN}^{-}$concentration, (b) varying $\mathrm{CN}^{-}$concentration and (c) a combination of $\mathrm{SCN}^{-}$and $\mathrm{CN}^{-}$. Error bars represent deviations.

hibited by the dual presence of $\mathrm{SCN}^{-}$and $\mathrm{CN}^{-}$, achieving ni-

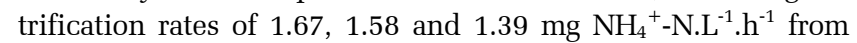
the initial concentrations of $\mathrm{CN}^{-}$and $\mathrm{SCN}^{-}$of 5,10 and $15 \mathrm{mg}$ $\mathrm{CN}^{-} \cdot \mathrm{L}^{-1}$ while the SCN${ }^{-}$concentration was kept at $25 \mathrm{mg} \mathrm{SCN} \cdot \mathrm{L}^{-1}$, respectively (Fig. 4(c)). Although there is a scarcity of information on alkaline nitrification, it has been observed that traditional 


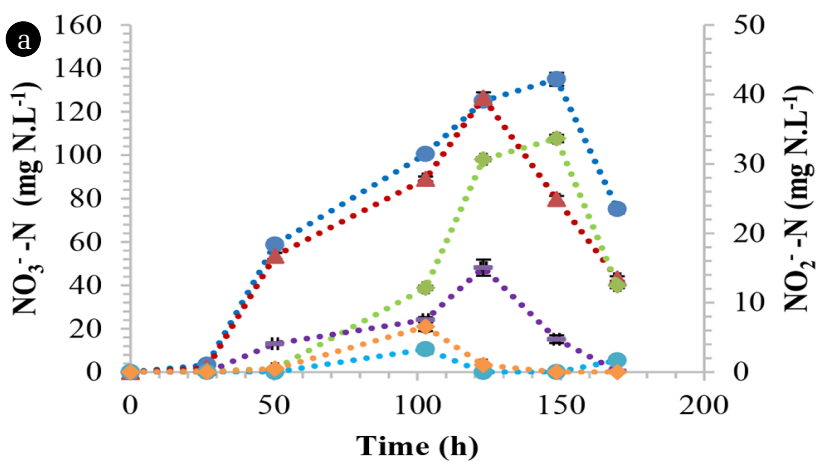

$\cdots \cdots$ Nitrate $(0 \mathrm{mg} / \mathrm{L} \mathrm{SCN}) \quad \cdots . . \cdot$ Nitrate $(25 \mathrm{mg} / \mathrm{L} \mathrm{SCN})$

$\cdots \cdots$ Nitrate $(50 \mathrm{mg} / \mathrm{L} \mathrm{SCN}) \quad \ldots \ldots$ Nitrite $(0 \mathrm{mg} / \mathrm{L} \mathrm{SCN}$

$\cdots \cdots$ Nitrite $(25 \mathrm{mg} / \mathrm{L} \mathrm{SCN}) \quad \ldots \ldots$ Nitrite $(50 \mathrm{mg} / \mathrm{L} \mathrm{SCN})$
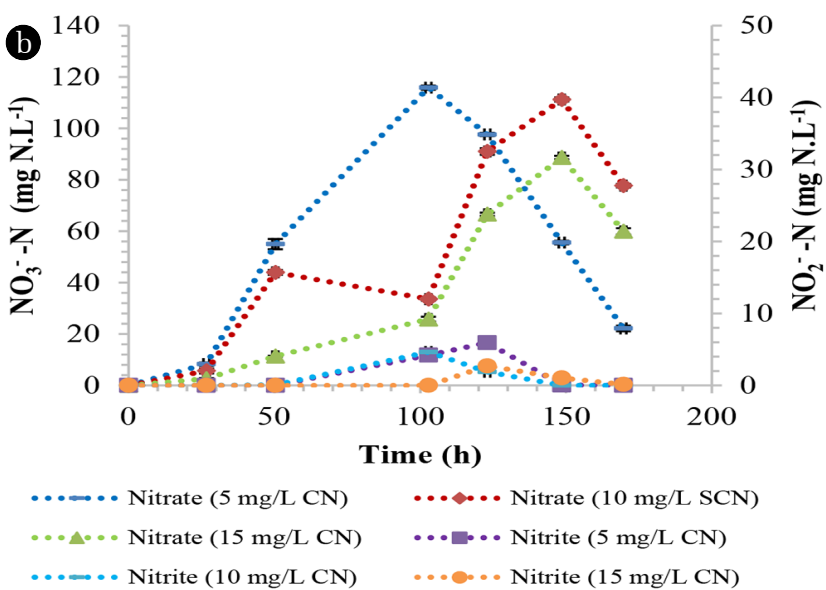

Nitrite $(10 \mathrm{mg} / \mathrm{L} \mathrm{CN}) \ldots .0$ Nitrite $(15 \mathrm{mg} / \mathrm{L} \mathrm{CN})$

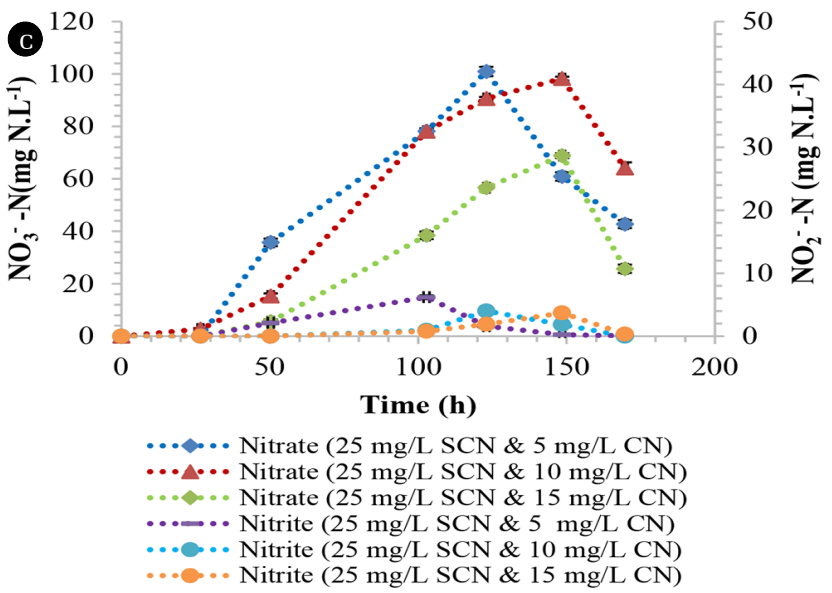

Fig. 5. Nitrate and nitrite formation profiles from heterotrophic nitrification by $\mathrm{CDO}$ under, (a) varying $\mathrm{SCN}^{-}$concentration, (b) varying $\mathrm{CN}^{-}$ concentration and (c) a combination of $\mathrm{SCN}^{-}$and $\mathrm{CN}^{-}$. Error bars represent deviations.

nitrifying organisms are unable to perform nitrification efficiently under highly alkaline conditions [25, 26] but high nitrification efficiencies are at $\mathrm{pH}$ ranges of 7.0 to 8.5 [27]. This study has shown that both the TDO's and CDO's were able to nitrify under alkaline conditions. The maximum concentrations of nitrate nitro- gen produced from the media supplemented with $0,25,50 \mathrm{mg}$ SCN. $\mathrm{L}^{-1}$ and 5, 10, $15 \mathrm{mg} \mathrm{CN} . \mathrm{L}^{-1}$ were 135, 126.5, 107.7 (Fig 5(a)) and 115.9, 111.2 and $88.7 \mathrm{mg} \mathrm{NO}{ }_{3}^{-} \mathrm{N}^{-L^{-1}}$, respectively (Fig. 5(b)). Similarly, the maximum nitrate nitrogen concentrations in cultures containing both $\mathrm{SCN}^{-}$and $\mathrm{CN}^{-}$were 100.95, 98.3 and $68.9 \mathrm{mg} \mathrm{NO}{ }^{-}-\mathrm{N}^{-1} \mathrm{~L}^{-1}$ (Fig. 5(c)). The nitrite concentration in all the tested media was less than $20 \mathrm{mg} \mathrm{NO}_{2}^{-}{ }^{-} \mathrm{N}^{-L^{-1}}$. These organisms, i.e. CDO's, were also observed to conduct nitrification and aerobic denitrification in a continuous $\mathrm{CN}^{-}$biodegradation process elsewhere [15], demonstrating their effectiveness as cyanide degraders, nitrifiers and denitrifiers.

\subsection{Effect of Thiocyanate and Free Cyanide on Aerobic Denitrification by TDO and CDO}

The aerobic denitrification potential of the TDO's and CDO's was evaluated under cyanogenic conditions, from an initial nitrate nitrogen concentration of $100 \mathrm{mg} \mathrm{NO}{ }_{3}^{-}-\mathrm{N} . \mathrm{L}^{-1}$. The TDO demonstrated the ability to denitrify aerobically as these species were able to achieve a complete denitrification rate of $0.66 \mathrm{mg} \mathrm{NO}{ }_{3}^{-}-\mathrm{N}^{-1} \mathrm{~L}^{-1} \cdot \mathrm{h}^{-1}$ in media supplemented with $0,25,50 \mathrm{mg} \mathrm{SCN} \cdot \mathrm{L}^{-1}$, respectively (Fig. 6(a)) with minimal detection of nitrites within the media $(\leq$ $0.04 \mathrm{mg} \mathrm{NO}{ }_{2}^{-}-\mathrm{N}^{-1} \mathrm{~L}^{-1}$ ) (data not shown). Similarly, $5 \mathrm{mg} \mathrm{CN} \mathrm{L}^{-1} \mathrm{did}$ not inhibit aerobic denitrification by these species since the denitrification rate exceeded $0.64 \mathrm{mg} \mathrm{NO}_{3}{ }^{-}-\mathrm{N} \cdot \mathrm{L}^{-1} \cdot \mathrm{h}^{-1}$. However, denitrification was inhibited by the presence of 10 and $15 \mathrm{mg} \mathrm{CN} \cdot \mathrm{L}^{-1}$, resulting in denitrification rates of 0.46 and $0.22 \mathrm{mg} \mathrm{NO}{ }^{-}-\mathrm{N}^{-} \mathrm{L}^{-1} \cdot \mathrm{h}^{-1}$, respectively (Fig 6(b)). Additionally, the dual effect of $\mathrm{CN}^{-}$and $\mathrm{SCN}^{-}$ proved to be detrimental, especially when the media was spiked with $25 \mathrm{mg} \mathrm{SCN} \cdot \mathrm{L}^{-1}$ and $10 \mathrm{mg} \mathrm{CN} \cdot \mathrm{L}^{-1}$, as well as $25 \mathrm{mg}$ SCN.L $\mathrm{L}^{-1}$ and $15 \mathrm{mg} \mathrm{CN} . \mathrm{L}^{-1}$, achieving denitrification rates of 0.39 and 0.11 mg $\mathrm{NO}_{3}^{-}-\mathrm{N} . \mathrm{L}^{-1} \cdot \mathrm{h}^{-1}$, respectively, while denitrification was unaffected by the presence of $25 \mathrm{mg} \mathrm{SCN} \cdot \mathrm{L}^{-1}$ and $5 \mathrm{mg} \mathrm{CN} \cdot \mathrm{L}^{-1}$ (Fig. 6(c)). The denitrification trends illustrated in Fig. 6(c) were similar to those observed in Fig. 6(b), which demonstrated the inhibitory effect that $\mathrm{CN}^{-}$had on the denitrification by the TDO's.

However, the CDO's demonstrated a high denitrification potential, as these species were not affected by the presence of $\mathrm{SCN}^{-}, \mathrm{CN}^{-}$ or the dual effect of $\mathrm{SCN}^{-}$and $\mathrm{CN}^{-}$. The denitrification rates were in excess of $0.67 \mathrm{mg} \mathrm{NO} \mathrm{NO}_{3}^{-} \mathrm{N} \cdot \mathrm{L}^{-1} \cdot \mathrm{h}^{-1}$ irrespective of toxicant concentration (Fig. 7(a) \& (b)). Aerobic denitrification was slightly inhibited when the media was spiked with $25 \mathrm{mg} \mathrm{SCN} \cdot \mathrm{L}^{-1}$ and $10 \mathrm{mg} \mathrm{CN} \cdot \mathrm{L}^{-1}$, and $25 \mathrm{mg} \mathrm{SCN} \cdot \mathrm{L}^{-1}$ and $15 \mathrm{mg} \mathrm{CN} \cdot \mathrm{L}^{-1}$, achieving denitrification rates of 0.6 and $0.54 \mathrm{mg} \mathrm{NO}{ }^{-}-\mathrm{N}^{-L^{-1}} \cdot \mathrm{h}^{-1}$ (Fig. 7(c)). Aerobic denitrification has been previously reported to produce nitrous oxide as an intermediate prior to the formation of nitrogen gas as summarised in Eq. (4). The enzymology involved in this process was explained elsewhere [28]. However, the production of nitrous oxide from aerobic denitrification systems has been largely investigated in axenic cultures [29, 30], which is not representative of microbial populations. The description of pathways and the enzymology associated with the production of nitrous oxide from aerobic denitrification systems in microbial populations has been reported to be challenging, since individual organisms within the population utilise different biochemical pathways for the utilisation of nitrates [31].

$$
\mathrm{NO}_{3}^{-} \rightarrow \mathrm{NO}_{2}^{-} \rightarrow \mathrm{NO} \rightarrow \mathrm{N}_{2} \mathrm{O} \rightarrow \mathrm{N}_{2}
$$



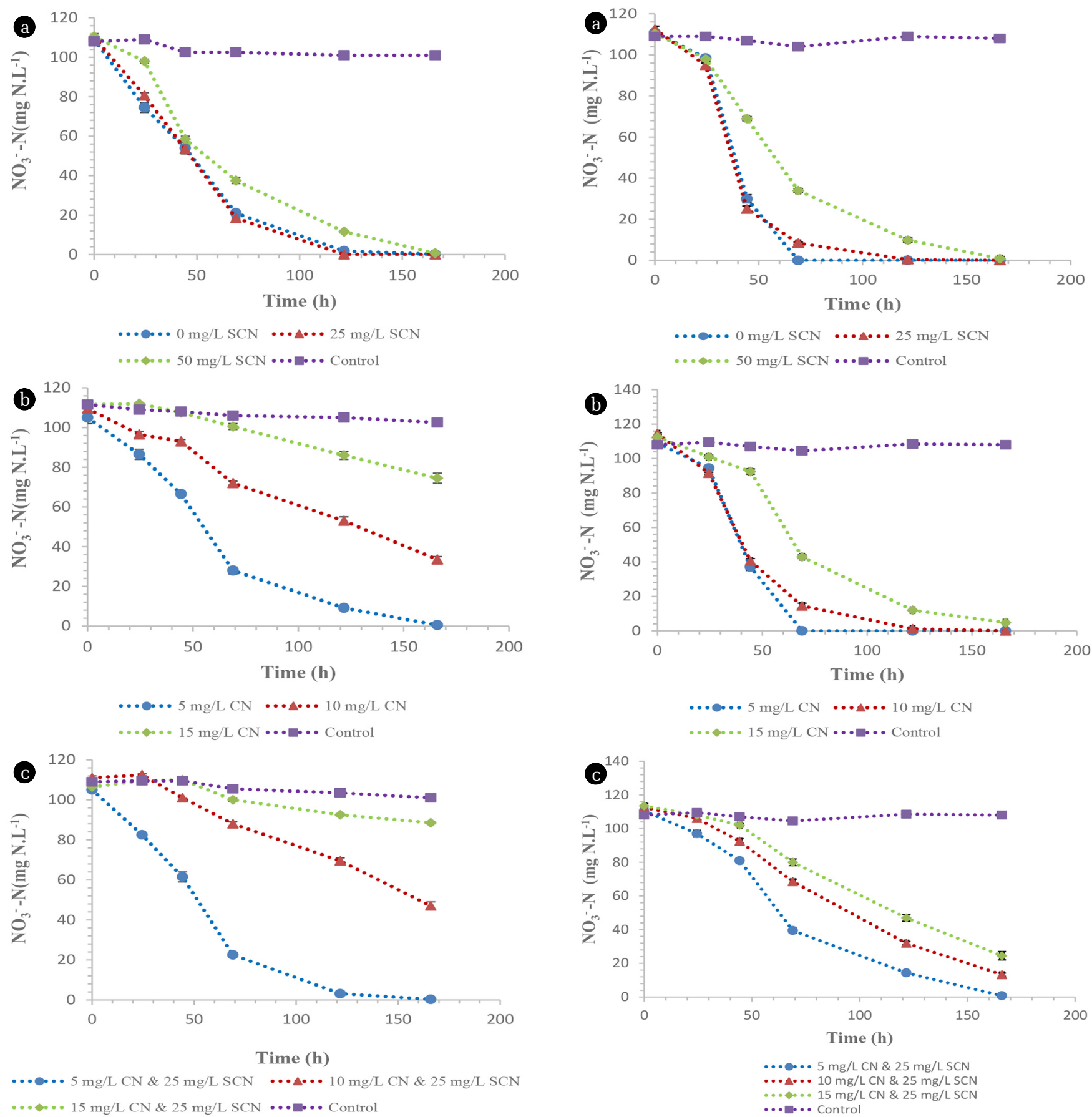

Fig. 6. Aerobic denitrification profiles by TDO under (a) varying SCN concentration, (b) varying $\mathrm{CN}^{-}$concentration and (c) a combination of $\mathrm{SCN}^{-}$and $\mathrm{CN}^{-}$. Error bars represent deviations.

\subsection{Simultaneous Heterotrophic Nitrification and Aerobic Denitrification by a Mixed Culture of TDO and CDO}

CDO's were co-cultured with the TDO's and evaluated for simultaneous nitrification and aerobic denitrification in the presence of $25 \mathrm{mg} \mathrm{SCN}{ }^{-} . \mathrm{L}^{-1}$ and $15 \mathrm{mg} \mathrm{CN} \mathrm{CN}^{-1}$. The co-culture was able

Fig. 7. Aerobic denitrification profiles by TDO under (a) varying SCN concentration, (b) varying $\mathrm{CN}^{-}$concentration and (c) a combination of $\mathrm{SCN}^{-}$and $\mathrm{CN}^{-}$. Error bars represent deviations.

to simultaneously nitrify and aerobically denitrify in the presence of $\mathrm{SCN}^{-}$and $\mathrm{CN}^{-}$, achieving nitrification and denitrification efficiencies of $100 \%$ (1.83 $\mathrm{mg} \mathrm{NH}_{4}{ }^{+}-\mathrm{N}^{-}{ }^{-1}$ ) (Fig. 8(a)). There was an observed nitrate nitrogen increase to $104 \mathrm{mg} \mathrm{NO}{ }_{3}^{-}-\mathrm{N} . \mathrm{L}^{-1}$ between $20 \mathrm{~h}$ to $100 \mathrm{~h}$; thereafter, the nitrate nitrogen concentration decreased. 


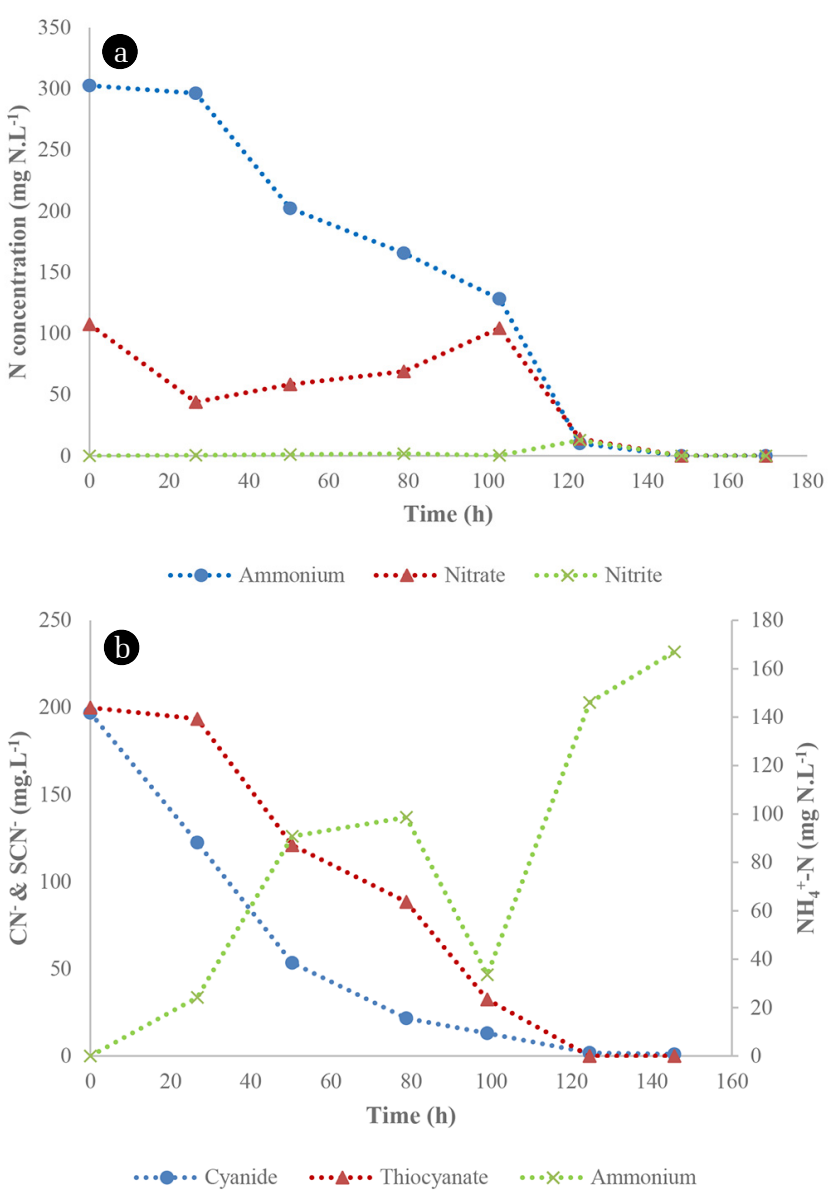

Fig. 8. Graphical representation of (a) simultaneous nitrification and denitrification and (b) simultaneous free cyanide and thiocyanate biodegradation by a mixed cultured of TDO and CDO's. Error bars represent deviations.

The co-culture was further evaluated for the simultaneous biodegradation of $\mathrm{CN}^{-}\left(200 \mathrm{mg} \mathrm{CN} \cdot \mathrm{L}^{-1}\right)$ and $\mathrm{SCN}^{-}\left(200 \mathrm{mg} \mathrm{SCN} \cdot \mathrm{L}^{-1}\right)$, resulting in complete degradation of $\mathrm{SCN}^{-}$after $124 \mathrm{~h}$ while the BRE of $\mathrm{CN}^{-}$exceeded 99\% (Fig. 8(b)). The ammonium nitrogen accumulated in the cultures was $98.7 \mathrm{mg} \mathrm{NH}{ }^{+}-\mathrm{N}^{-L^{-1}}$ after 78

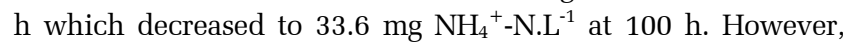
there was an observed ammonium accumulation within the cultures after $100 \mathrm{~h}$, escalating to $167 \mathrm{mg} \mathrm{NH}_{4}{ }^{+}-\mathrm{N}_{\mathrm{L}} \mathrm{L}^{-1}$ at $146 \mathrm{~h}$. This increase was due to ammonium production from the biodegradation of $\mathrm{CN}^{-}$and $\mathrm{SCN}^{-}$as described in Eq. (1) and (2). Simultaneous nitrification and aerobic denitrification has been reported in various studies [6, 32]. However, these studies were undertaken under $\mathrm{SCN}^{-}$and $\mathrm{CN}^{-}$free systems. Nitrification under $\mathrm{CN}^{-}$laden conditions was investigated using activated sludge obtained from a coking wastewater treatment plant and in this study, nitrification was inhibited when the media was supplemented with $0.2 \mathrm{mg} \mathrm{CN} \cdot \mathrm{L}^{-1}[9]$, with $\mathrm{SCN}^{-}$having a minimal inhibitory effect on nitrification. While in a separate study, the Enterobacter, Yersinia, and Serratia species were able to carry out nitrification under cyanogenic conditions (66 mg CN$\cdot \mathrm{CN}^{-1}$ ), with minimal inhibition [33]. The high $\mathrm{CN}^{-}$tolerance was attributed to the differences in composition, strength and overall quality of the microbial consortia used [34]. This study demonstrated the robustness of heterotrophic nitrification and aerobic denitrification under $\mathrm{CN}^{-}$ and $\mathrm{SCN}^{-}$laden conditions, when subjected to a mixed culture of TDO's and CDO's.

\section{Conclusions}

Heterotrophic nitrification and aerobic denitrification under SCN and $\mathrm{CN}^{-}$laden conditions by $\mathrm{SCN}^{-}$and $\mathrm{CN}^{-}$degrading organisms was successfully demonstrated, particularly in co-cultures. $\mathrm{CN}^{-}$ $\left(\geq 10 \mathrm{mg} \mathrm{CN} \cdot \mathrm{L}^{-1}\right.$ ) inhibited nitrification and denitrification in media inoculated with $\mathrm{SCN}^{-}$degrading organisms (TDO's), while the $\mathrm{CN}^{-}$degrading organisms (CDO's) were not inhibited by $\mathrm{SCN}^{-}$ nor $\mathrm{CN}$, irrespective of the concentration load. Additionally, the presence of both $\mathrm{CN}^{-}\left(\geq 10 \mathrm{mg} \mathrm{CN} \cdot \mathrm{L}^{-1}\right)$ and $\mathrm{SCN}^{-}\left(25 \mathrm{mg} \mathrm{SCN} \cdot \mathrm{L}^{-1}\right)$ inhibited nitrification and aerobic denitrification by the thiocyanate degraders while the cyanide degraders were not inhibited. A mixed culture containing both $\mathrm{SCN}^{-}$and $\mathrm{CN}^{-}$degraders was able to nitrify and aerobically denitrify without being inhibited by the presence of both $\mathrm{SCN}^{-}$and $\mathrm{CN}^{-}$, irrespective of the toxicant concentration load. This demonstrated the robustness and effectiveness of these organisms to carry out heterotrophic nitrification and aerobic denitrification under cyanogenic conditions - a process which can be applied to the nitrification and denitrification of ammonium nitrogen and nitrates formed from $\mathrm{CN}^{-}$and $\mathrm{SCN}^{-}$ biodegradation systems. The data signifies that the influx of these toxicants into secondary processes (nitrification and denitrification) will not have an inhibitory effect on nitrification and denitrification since these organisms are able to degrade, nitrify and denitrify. Therefore, these organisms can be utilized for the treatment of cyanide-laden wastewaters including the treatment of the by or end-products of the biodegradation process. However, future studies should focus on the biochemical mechanisms of heterotrophic nitrification and aerobic denitrification.

\section{Acknowledgments}

The authors would like to acknowledge the Cape Peninsula University of Technology (CPUT), University Research Fund (URF RK 16) and the National Research Foundation (NRF) Innovation Scholarship (Grant no:95550)for providing funding for this project.

\section{References}

1. Johnson CA. The fate of cyanide in leach wastes at gold mines: An environmental perspective. Appl. Geochem. 2015;57:194-205.

2. Yao S, Ni J, Ma T, Li C. Heterotrophic nitrification and aerobic denitrification at low temperature by a newly isolated bacterium, Acinetobacter sp. HA2. Bioresour. Technol. 2013;139:80-86.

3. Joo HS, Hirai M, Shoda M. Characteristics of ammonium re- 
moval by heterotrophic nitrification-aerobic denitrification by Alcaligenes faecalis No. 4. J. Biosci. Bioeng. 2005;100:184-191.

4. Chen Q, Ni J. Heterotrophic nitrification - Aerobic denitrification by novel isolated bacteria. J. Ind. Microbiol. Biotechnol. 2011;38:1305-1310.

5. Zhang QL, Liu Y, Ai GM, Miao LL, Zheng HY, Liu ZP. The characteristics of a novel heterotrophic nitrification - Aerobic denitrification bacterium, Bacillus methylotrophicus strain L7. Bioresour. Technol. 2012;108:35-44.

6. Zhang J, Wu P, Hao B, Yu Z. Heterotrophic nitrification and aerobic denitrification by the bacterium Pseudomonas stutzeri YZN-001. Bioresour. Technol. 2011;102:9866-9869.

7. Chen P, Li J, Li QX, et al. Simultaneous heterotrophic nitrification and aerobic denitrification by bacterium Rhodococcus sp. CPZ24. Bioresour. Technol. 2012;116:266-270.

8. Liu Y, Wang Y, Li Y, An H, Lv Y. Nitrogen removal characteristics of heterotrophic nitrification-aerobic denitrification by Alcaligenes faecalis C16. Chinese J. Chem. Eng. 2015;23:827-834.

9. Kim YM, Park D, Lee DS, Park JM. Inhibitory effects of toxic compounds on nitrification process for cokes wastewater treatment. J. Hazard. Mater. 2008;152:915-921.

10. Mekuto L, Ntwampe SKO, Mudumbi JBN, Akinpelu EA, Mewa-Ngongang M. Metagenomic data of free cyanide and thiocyanate degrading bacterial communities. Data Brief 2017;13:738-741.

11. Mekuto L, Alegbeleye OO, Ntwampe SKO, Ngongang MM, Mudumbi JB, Akinpelu EA. Co-metabolism of thiocyanate and free cyanide by Exiguobacterium acetylicum and Bacillus marisflavi under alkaline conditions. 3 Biotech. 2016;6:173.

12. Mekuto L, Ntwampe SKO, Jackson VA. Biodegradation of free cyanide using Bacillus sp. consortium dominated by Bacillus Safensis, Lichenformis and Tequilensis strains: A bioprocess supported solely with whey. J. Bioremediate. Biodegrad. 2013;S18:004.

13. Santos BAQ, Ntwampe SKO, Doughari JH. Continuous biotechnological treatment of cyanide contaminated waters by using a cyanide resistant species of Aspergillus awamori. In: Environmental biotechnology. Rijeka; INTECH; 2013. Ch. 06. p. 123-146.

14. Akcil A, Mudder T. Microbial destruction of cyanide wastes in gold mining: Process review. Biotechnol. Lett. 2003;25:445-450.

15. Mekuto L, Ntwampe SKO, Jackson VA. Biodegradation of free cyanide and subsequent utilisation of biodegradation by-products by Bacillus consortia: Optimisation using response surface methodology. Environ. Sci. Pollut. Res. 201;22:10434-10443.

16. Katayama Y, Narahara Y, Inoue Y, Amano F, Kanagawa T, Kuraishi H. A thiocyanate hydrolase of Thiobacillus thioparus. A novel enzyme catalyzing the formation of carbonyl sulfide from thiocyanate. J. Biol. Chem. 1992;267:9170-9175.

17. Chaudhari A, Kodam K. Biodegradation of thiocyanate using co-culture of Klebsiella pneumoniae and Ralstonia sp. Appl. Microbiol. Biotechnol. 2010;85:1167-1174.

18. Jeong YS, Chung JS. Biodegradation of thiocyanate in biofilm reactor using fluidized-carriers. Process Biochem. 2006;41:701-707.
19. Akcil A. Destruction of cyanide in gold mill effluents: Biological versus chemical treatments. Biotechnol. Adv. 2003;21:501-511.

20. Sorokin DY, Tourova TP, Lysenko AM, Kuenen JG. Microbial thiocyanate utilization under highly alkaline conditions. Appl. Environ. Microbiol. 2001;67:528-538.

21. Sorokin DY, Tourova TP, Antipov AN, Muyzer G, Kuenen JG. Anaerobic growth of the haloalkaliphilic denitrifying sulfur-oxidizing bacterium Thialkalivibrio thiocyanodenitrificans sp. nov. with thiocyanate. Microbiology 2004;150:2435-2442.

22. Neufeld R, Greenfield J, Rieder B. Temperature, cyanide and phenolic nitrification inhibition. Water Res. 1986;20:633-642.

23. Robertson LA, Van Niel EW, Torremans RA, Kuenen JG. Simultaneous nitrification and denitrification in aerobic chemostat cultures of Thiosphaera pantotropha. Appl. Environ. Microbiol. 1988;54:2812-2818.

24. Gupta AB. Thiosphaera pantotropha: A sulphur bacterium capable of simultaneous heterotrophic nitrification and aerobic denitrification. Enzyme Microb. Technol. 1997;21:589-595.

25. Ruiz G, Jeison D, Chamy R. Nitrification with high nitrite accumulation for the treatment of wastewater with high ammonia concentration. Water Res. 2003;37:1371-1377.

26. Strous M, Van Gerven E, Zheng P, Kuenen JG, Jetten MSM. Ammonium removal from concentrated waste streams with the anaerobic ammonium oxidation (Anammox) process in different reactor configurations. Water Res. 1997;31:1955-1962.

27. Koren DW, Gould WD, Bédard P. Biological removal of ammonia and nitrate from simulated mine and mill effluents. Hydrometallurgy 2000;56:127-144.

28. Robertson LA, Kuenen JG. Aerobic denitrification - Old wine in new bottles? Antonie van Leeuwenhoek 1984;50:525-544.

29. Chen F, Xia Q, Ju LK. Aerobic denitrification of Pseudomonas aeruginosa monitored by online NAD (P) H fluorescence. Appl. Environ. Microbiol. 2003;69:6715-6722.

30. Takaya N, Catalan-Sakairi MAB, Sakaguchi Y, Kato I, Zhou Z, Shoun H. Aerobic denitrifying bacteria that produce low levels of nitrous oxide. Appl. Environ. Microbiol. 2003;69:3152-3157.

31. Ishii S, Song Y, Rathnayake L, et al. Identification of key nitrous oxide production pathways in aerobic partial nitrifying granules. Environ. Microbiol. 2014;16:3168-3180.

32. He T, Li Z, Sun Q, Xu Y, Ye Q. Heterotrophic nitrification and aerobic denitrification by Pseudomonas tolaasii Y-11 without nitrite accumulation during nitrogen conversion. Bioresour. Technol. 2016;200:493-499.

33. Mpongwana N, Ntwampe SKO, Mekuto L, Akinpelu EA, Dyantyi S, Mpentshu Y. Isolation of high-salinity-tolerant bacterial strains, Enterobacter sp., Serratia sp., Yersinia sp., for nitrification and aerobic denitrification under cyanogenic conditions. Water Sci. Technol. 2016;73:2168-2175.

34. Kim YM, Lee DS, Park C, Park D, Park JM. Effects of free cyanide on microbial communities and biological carbon and nitrogen removal performance in the industrial activated sludge process. Water Res. 2011;45:1267-1279. 